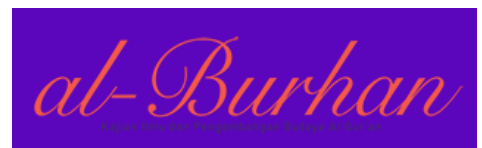

\title{
DISKURSUS TAFSIR MAQĀṢIDI
}

\section{Maqāṣidi Interpretation Discourse}

\section{Made Saihu}

Institut PTIQ Jakarta, Indonesia

madesaihu@ptiq.ac.id

\begin{abstract}
Abstrak:
Diskursus tafsir maqasidi sebagai bentuk respons metodologi tafsir terhadap situasi terkini yang dihadapi. Respons ini dinilai sebagai salah satu upaya penyingkronan ajaran agama terhadap perkembangan dan penafsiran serta sosial kemasyarakatan. Eksplanasi dalam tulisan ini bersifat deskriptif sebagai bentuk upaya pemahaman terhadap eksistensi sebagai tafsir maqasidi di era modern. Ini berarti tafsir maqasidi sebagai tafsir modern melakukan konstruksi karya-karya tafsir masa lalu atau klasik menggunakan metode interpretif yang berkembang di masa kontemporer.
\end{abstract}

Kata Kunci: Diskursus, Tafsir, Maqasidi, Metode, Modern.

\begin{abstract}
:
Maqasidi interpretation discourse as a form of response methodology of interpretation to the current situation faced. This response is considered as one of the efforts to synchronize religious teachings to the development and interpretation as well as social society. The explanation in this paper is descriptive as an effort to understand the existence as a maqasidi interpretation in the modern era. This means that maqasidi interpretation as a modern interpretation performs the construction of works of past or classical interpretation using interpretive methods that have developed in contemporary times.
\end{abstract}

Keywords: Discourse, Tafsir, Maqasidi, Method, Modern.

$$
\begin{aligned}
& \text { الملخص: } \\
& \text { خطاب التفسير المقاصد كشكل من أشكال منهجية الاستجابة للتفسير للوضع الحالي الذي يواجهه. تعتبر هذه } \\
& \text { الاستجابة واحدة من الجهود المبذولة لمزامنة التعاليم الدينية مع التنمية والتفسير وكذلك المجتمع الاجتماعي. } \\
& \text { التفسير في هذه الورقة وصفي بطبيعته كمحاولة لفهم الوجود كتفسير مقاصدي في العصر الحديث. هذا يعني أن } \\
& \text { تفسير المقاصد كتفسير حديث يقوم ببناء أعمال التفسير الماضي أو الكلاسيكي باستخدام الأساليب التفسيرية } \\
& \text { التي تطورت في الأزمنة المعاصرة. } \\
& \text { الكلمات المفتاحية: الخطاب، التفسير، المقاصد، الأسلوب، الحديث. }
\end{aligned}
$$




\section{Pendahuluan}

Tafsir al-Qur'an sebagai salah satu sarana untuk memahami isi kandungan alQur'an terus dikaji. Dan kajian tentang tafsir al-Qur'an dan metodologinya terus berkembang dari masa kemasa untuk mencari metodologi yang dianggap paling sesuai dengan konteks dan tuntutan zamannya, berbagai metode telah dikemukakan oleh para mufassirin dan masing-masing generasi bertanggung jawab untuk memperbarui atau menyegarkan kembali studi sebelumnya, yang dianggap tidak relevan. ${ }^{1}$ Adanya metode tafsir modern kontemporer disebabkan salah satunya oleh munculnya kekhawatiran yang diakibatkan manakala penafsiran terhadap al-Qur'an dilakukan secara sembrono dan secara tekstual, dengan mengenyampingkan sisi situasi dan historisitas turunnya ayat, dan ini menjadi salah satu fakta sejarah yang tidak begitu saja diabaikan.

\section{Melacak Sejarah dan Karakteristik Tafsir Modern-Kontemporer}

Metode tafsir modern atau kontemporer merupakan metode penafsiran terhadap al-Qur'an yang menempatkan problematika kemanusiaan sebagai ruh penafsiran. Problematika tersebut kemudian diteliti dan dianalisis melalui beragam pendekatan yang tepat dan sesuai dengan persoalan disertai sebab-sebab yang melatarinya. ${ }^{2}$ Selain itu, survei terhadap corak gagasan para ahli tafsir modern, yang dilakukan Jansen, menunjukkan adanya tiga peta pemikiran; corak pemikiran tafsir 'ilmī, corak pemikiran tafsir filologi, dan corak pemikiran tafsir adab ijtimā $\bar{\imath} .{ }^{3}$

Menurut sejumlah ahli tentang al-Qur'an, yang didasari oleh temuan sejumlah ulama kontemporer, bahwa metode tafsir atas al-Qur'an dibagi menjadi empat

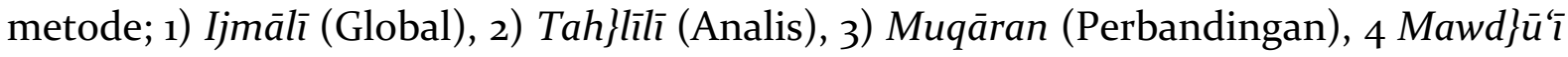
(Tematik). Ada satu metode lagi, yaitu metode kontekstual (tafsir terhadap al-Qur'an berbasis historis, sosiologi, budaya, adat istiadat, dan pranata yang berkembang dalam masyarakat Arab, baik sebelum atau sesudah al-Qur'an diturunkan. Metode terakhir ini termasuk kategori tafsir kontemporer.

\section{Pengertian Tafsir Modern}

Ada dua kata yang terkandung dalam kalimat tersebut, yakni tafsir dan

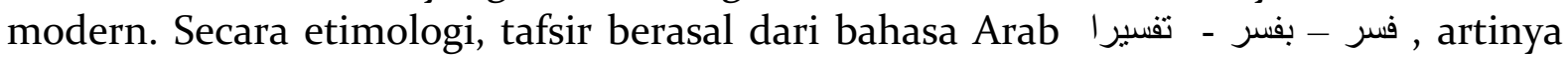
memeriksa, memperlihatkan, atau bermakna kata الايضاح والثرح, penjelasan atau komentar. Sedangkan secara terminologi, tafsir adalah penjelasan terhadap kalām Allāh atau menjelaskan lafal-lafal al-Qur'an dan pemahamannya. Menurut al-Zarkasyi, yang dikutip 'Abd al-Qādir Muhammad Șāliḥ, dalam kitabnya, al-Tafsīr wa alMufassirūn fí 'așr al-Hadìth, tafsir adalah ilmu yang digunakan untuk memahami Kitab Allah yang diturunkan kepada nabi-Nya, Muhammad Saw, dan menjelaskan makna-

${ }^{1}$ Muhammad Hariyadi, "METODOLOGI TAFSIR AL-QUR'AN KONTEMPORER SALAM PENDEKATAN ILMU KOMUNIKASI MODERN," Jurnal Statement 11, no. 1 (2021): 30-40.

${ }^{2}$ Muhammad Hariyadi and Yusuf Arbi, "Eksposisi Nalar Tafsir Kiai Sholeh Darat; Telaah Transmisi Keilmuan Dan Kontekstualitas Kitab Faidh Ar-Rahman Fi Tarjamah Tafsir Kalam Malik AdDayyan," Al-Burhan: Jurnal Kajian Ilmu Dan Pengembangan Budaya Al-Qur'an 19, no. 1 (2019): 1-30. xii-xvi.

3 J. J. G. Jansen, Diskursus Tafsir Islam Modern (Terj.) (Yogyakarta: Tiara Wacana Yogya: 1997), 166| al-oßurhan: Kajian Ilmu dan Pengembangan Budaya Al-Qur'an, Vol. 2o, No. 2, Desember 2020: 165-179. 
maknanya serta mengeluarkan hukum-hukum dan hikmahnya. ${ }^{4}$ Lebih jelas lagi, dapat dilihat beberapa terminologi dari beberapa ulama. Menurut Muh\}ammad Husayn alDhahabī, dalam kitabnya, al-Tafsīr wa al-Mufassirūn. ${ }^{5}$ Tafsir menurut bahasa maknanya menjelaskan dan menerangkan. Sedangkan menurut istilah ialah menjelaskan kalam Allah dan atau menjelaskan lafal-lafal al-Qur'an dan pemahamanpemahamannya.

Secara teoretis, tafsir berarti usaha untuk memperluas makna teks al-Qur'an. Sedangkan secara praktis berarti usaha untuk mengadaptasikan, mengkontekstualkan “Teks al-Qur'an dengan situasi kontemporer seorang mufasir. Berarti tafsir modern adalah; usaha untuk menyesuaikan dan atau mengkontekstualisasikan ayat-ayat alQur'an dengan tuntutan zaman.” Karena itu, tafsir al-Qur'an adalah bentuk ilmu pengetahuan dalam rangka untuk memahami dan menafsirkan ayat al-Qur'an dan isinya. Fungsinya adalah sebagai pemberi penjelasan (mubayyin). Selain itu juga untuk menjelaskan arti dan kandungan al-Qur'an, terutama terkait ayat-ayat yang sulit dipahami dan artinya masih samar. ${ }^{6}$ Dalam upaya memahami dan menafsirkan alQur'an dibutuhkan berbagai ragam ilmu pengetahuan yang bertalian dengan Qur'an dan isinya, dan tidak sekadar pengetahuan kebahasa-Araban semata. Dalam Kamus Besar Bahasa Indonesia, 'modern' bermakna terbaru atau mutakhir. Sedangkan kontemporer bermakna pada waktu yang sama, semasa, sewaktu, pada masa kini, dewasa ini. ${ }^{7}$

Tak ada kesepakatan yang jelas tentang istilah kontemporer. Misalnya, apakah yang dimaksud kontemporer itu mencakup abad IX atau hanya abad XX atau XXI. Menurut sejumlah ahli, bahwa yang dimaksud kontemporer itu adalah modern. Ini artinya, keduanya identik dan digunakan saling bergantian. Dalam konteks peradaban Islam, kontemporer dan modern digunakan ketika terjadi persentuhan intelektual dunia Islam dengan dunia Barat. Tidak berlebihan ketika kontemporer merujuk kepada pengertian era yang memiliki relevansi dengan tuntutan kehidupan modern. Oleh karena itu, dapat disimpulkan bahwa tafsir kontemporer adalah tafsir atau penjelasan tentang ayat-ayat al-Qur'an yang dikompatibelkan dengan situasi terkini. Pengertian ini searah dengan pengertian tajdìd, yaitu upaya penyesuaian ajaran agama dengan situasi kontemporer melalui penafsiran atau pentakwilan yang disesuaikan dengan dinamika ilmu pengetahuan dan sosial kemasyarakatan. ${ }^{8}$

Metode penafsiran kontemporer dan modern adalah suatu metode penafsiran Qur'an dengan menjadikan problematika manusia sebagai ruh penafsirannya. Berdasarkan masalah yang mereka hadapi dan alasan yang melatarbelakanginya, dipelajari dan dianalisis dengan berbagai cara. Masalah kemanusiaan dihadapi adalah

\footnotetext{
4 'Abd al-Qādir Muhammad Șaliḥ, al-Tafsīr wa al-Mufassirūn fi al-'Așr Hadīth (Beirut: Dār alMa'rifah, 2003), 82.

${ }^{5}$ Muhammad Ḥusayn al-Dhahabī, al-Tafsīr wa al-Mufassirūn (Kairo: Dār al-Hadìth, 2012), 18.

${ }^{6}$ Munif Mahadi Attamimi and Muhammad Hariyadi, "Al-Qur' an Answering the Challenge of Human

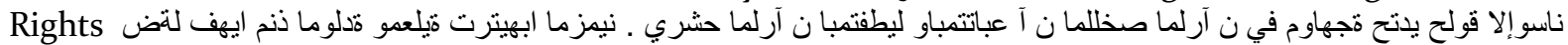

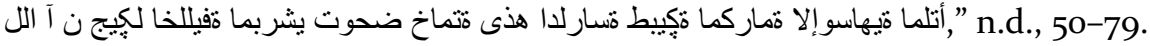

${ }^{7}$ Departemen Pendidikan Nasional, Kamus Besar Bahasa Indonesia, Jakarta: Pustaka Utama, 2012. Ed. Keempat. hal. 924, 729. Islamy, Athoillah. "Existence Existence Of Naht Method In The Development Of Contemporary Arabic Language." Taqdir 5.2 (2019): 19-28.

${ }^{8}$ Mubin, Fatkhul, and Abd Aziz. "Politik Pendidikan Islam Indonesia: Perlawanan Pesantren Terhadap Hegemoni Pendidikan Barat Era Kolonialisme Belanda." Al Amin: Jurnal Kajian Ilmu dan Budaya Islam 3.1 (2020): 123-136.
}

at- ¿urhan: Kajian Ilmu dan Pengembangan Budaya Al-Qur'an, Vol. 20, No. 2, Desember 2020: 165-179 | 167 
masalah kemiskinan, kesehatan, pengangguran, hukum, ketidakadilan, politik, ekonomi, budaya, diskriminasi, gender, hak asasi manusia, dan ketidaksetaraan lainnya. Dengan begitu, metodologi penafsiran kontemporer adalah studi seputar metode interpretif yang berkembang di era kontemporer. Jika tidak dicermati, pengertian di atas akan menyesatkan, karena memberikan kesan bahwa al-Qur'an harus mengikuti dinamika zaman, yang pernyataan tersebut tidak sembarang orang dapat mengatakannya. Secara detail pengertian tafsir modern adalah merekonstruksi produk tafsir klasik yang tidak ada sangkut pautnya dengan kondisi modern.

\section{Sejarah Munculnya Tafsir Modern-Kontemporer}

Abad XIX atau abad XV merupakan abad dunia Islam meningkat ke arah yang lebih maju dalam berbagai aspek. Termasuk di dalamnya aspek tafsir, dan banyak sejumlah karya tafsir berasal dari ulama abad tersebut. Studi tentang Qur'an dalam khazanah intelektual Islam tidak pernah berhenti. Setiap generasi bertanggung jawab memperbarui studi sebelumnya yang dianggap usang.

Salah satu pemicu munculnya metode tafsir kontemporer adalah adanya kekhawatiran yang akan terjadi manakala penafsiran terhadap al-Qur'an dilakukan secara tekstual, disertai sikap abai terhadap situasi dan histori turunnya suatu ayat sebagai data sejarah. ${ }^{9}$ Seorang pembaharu Islam di Delhi, dan juga sosok yang menggagas penulisan tafsir moder, Shah Waliyullah (1701-1762), memiliki dua karya penting; Hujjah al-Bālighah dan Ta'wīl al-Hadìth fì Rumūz Qiṣaṣ al-Anbiyā', yang substansinya tentang gagasan-gagasan modern. Jejak ini selanjutnya diikuti oleh sejumlah pembaharu Islam lainnya di Mesir, untuk melakukan hal yang sama. Misalnya, sekadar menyebut; tafsir karya Muḥammad 'Abduh, Rashīd Ridā, Aḥmad Khalaf, dan Muhammad Kāmil Ḥusayn. Di wilayah Indo-Pakistan, sebut saja ada Abū Azad, al-Masriqqi, G.A Parws, dan lainnya. Sementara itu, di Timur Tengah, sebut saja muncul Amīn al-Khullī (w. 1978), Ḥasan Ḥanafī , Bint Shāṭī (w. 200o), Naṣr Abū Zayd, Muhammad Shahrur, dan Fazlur Rahman.

\section{Perkembangan Tafsir Modern-Kontemporer}

Apa saja mengalami perkembangan, sudah pasti mempunyai proses perubahan bentuk atau sifat. Al-Qur'an, bentuknya tidak berubah, karena merupakan 'teks baku' atau 'teks mati,' sejalan terhentinya proses penurunan wahyu, sehingga tidak lagi mengalami perkembangan untuk menjawab problematika kehidupan, sebagaimana terjadi ketika proses pewahyuan. ${ }^{10}$ Tetapi, kandungan maknanya senantiasa seiring dengan dinamika zaman. Inilah yang diyakini muslim bahwa al-Qur'an itu bersifat raḥmat li al-'álamin atau rahmat untuk semua manusia dan makhluk di bumi. Tentunya tidak hanya dilihat dari sisi kata raḥmat li al-ālamīn, namun juga perlu dilihat dari sisi proses sejalannya dengan perubahan zaman. Ini sebuah metode pemaknaan atas sejumlah ayat Qur'an yang merujuk kepada ketentuan-ketentuan penafsiran yang disepakati ulama, yang kemudian model penafsiran ini dinamakan dengan penafsiran kontekstual. Pada dasarnya, model penafsiran ini sejak masa Islam

\footnotetext{
${ }^{9}$ Ignas Goldziher, Madzhab Tafsir: dari Aliran Klasik hingga Modern (Terj) (Yogyakarta: el SAQ Press. 2003), 100.

${ }^{10}$ Nur Arfiyah Febriani et al., "GLOBAL CITIZENSHIP EDUCATION IN THE PERSPECTIVE OF QUR' AN AND,” Psychology and Education Journal 57, no. 57 (2020): 5020-29. 168| al- Burhan: Kajian Ilmu dan Pengembangan Budaya Al-Qur'an, Vol. 20, No. 2, Desember 2020: $165-179$.
} 
awal sudah ada, yakni pada masa nabi Muhammad Saw, sehingga penafsiran kontekstual ini diterapkan oleh kaum muslim klasik (salaf) dan muslim kontemporer (khalaf). Selanjutnya akan dibahas beberapa tinjauan tentang sejarah perkembangan tafsir ini yakni dari segi metode penafsiran, kodifikasi tafsir dan terakhir ditinjau dari corak penafsiran.

\section{Periodisasi Tafsir Modern-Kontemporer}

Bila merefer kepada buku, Mazhab Tafsir, karya Abdul Mustaqim, pengertian era modern berbeda dengan pengertian era kontemporer. Kendati pengertian keduanya memiliki perbedaan, yang jelas masa kontemporer adalah masa kelanjutan dari masa modern, sehingga kedua masa tersebut tidak dapat dipisahkan satu sama lainnya. Maka itu, ada penjelasan dari Hasbi ash-Shiddiqie, terkait periodisasi tafsir. Menurutnya, ada delapan periode tafsir: 1) periode abad I dan II hijriah; 2) periode abad III hijriah; 3) periode abad IV hijriah; 4) periode abad V dan VI hijriah; 5) periode abad VII dan VIII; 6) periode abad IX dan X; 7) periode abad XI, XII, XIII; 8) periode abad XIV. Tidak ada alasan yang diutarakan terkait periode penafsiran yang disatukan.

Berdasarkan periodisasi yang dibuat T. M. Hasbi Ash-Shiddieqy, kedudukan tafsir modern dan kontemporer dengan metode tahlīlì, terletak pada periode kedelapan, yaitu abad XIV H. Periode ke-8 tersebut menggabungkan era modern dan kontemporer. Tafsir pada periode tersebut dikomandani Muhammad 'Abduh dan Muhłammad Rashīd Rị̣ā dengan tafsirnya, al-Manār, dan Jamāl al-Dīn al-Qāsimī dengan tafsirnya, Taḥsīn al-al-Ta'wīl, Țanțāwī Jawharī dengan tafsirnya, al-Jawāhir, dan Muhạmmad 'Abd al-'Azīz al-H\{ākim dengan tafsirnya, al-Futūhāt al-Rabbānìyah. Setelahnya, karya lain muncul, seperti karya Aḥmad Musṭafā al-Marāghī, berjudul Tafsīr al-Marāghī, dan sebagainya."

Sedangkan periode tafsir, oleh Quraish Shihab, dibagi menjadi dua. Pertama, periode pertama masa nabi, sahabat, dan tabiin, yang berakhir pada berakhirnya periode masa tabiin, yakni tahun 150-an H. Dalam periode pertama tersebut, muncul corak tafsir bi al-ma'thūr. Kedua, periode kedua, yang dimulai dari tahun $150 \mathrm{H}$ sekarang. Dalam periode ini, berkembang tafsir bi al-ra'y-u dengan beragam corak penafsirannya, yakni kurang lebih ada enam corak di dalamnya; corak sastra bahasa, corak filsafat dan teologi, corak ilmiah, corak fikih atau hukum, corak tasawuf, dan corak sastra budaya kemasyarakatan. Periodisasi yang dijelaskan M. Quraish Shihab, kedudukan tafsir modern dan kontemporer dengan metode tahlīlī terletak di periode kedua. Periode modern dan kontemporer disatukan dalam ke dalam satu periode.

Periodisasi tafsir dibagi menjadi tiga oleh Nashrudin Baidan. Periode pertama, periode ulama mutaqaddimin, dari abad III-VIII H atau abad IX-XIII M. Periode kedua, periode ulama muta'akhirinn, dari abad IX-XII H atau XIII-IXX M. Periode ketiga, periode ulama modern, dari abad XVI H-sekarang atau IXX M-sekarang. ${ }^{12}$ Menurut Nashruddin Baidan, berdasarkan periodisasi tafsir, posisi tafsir modern dan kontemporer yang menggunakan metode tahlìlì, terletak pada periode ketiga. Masa modern dan masa kontemporer digabung menjadi satu periode.

${ }^{11}$ Teungku Muhammad Hasbi ash Shiddiqy. Sejarah dan Pengantar Ilmu al Qur'an dan Tafsir (Semarang: Pustaka Rizki Putra. 2009), 175-201.

${ }^{12}$ Nasirudin Baidan, Perkembangan Tafsir al-Qur'an di Indonesia (Solo: Tiga Serangkai Pustaka Mandiri. 2003), 78.

al-§urhan: Kajian Ilmu dan Pengembangan Budaya Al-Qur'an, Vol. 20, No. 2, Desember 2020: 165-179 | 169 
Ketiga periodisasi perkembangan tafsir tersebut menjadi rujukan Hasbi AhShiddieqy, M. Quraish Shihab, dan Nashrudin Baidan. Dari sisi waktu, ketiga periodisasi tersebut menunjukkan bahwa masa modern dan kontemporer itu sama. Dari aspek substansi, perkembangan tafsir modern dan kontemporer dengan metode tah\}līì dapat ditelusuri melalui karakteristik perkembangan tafsir itu sendiri, baik bertalian dengan isi, metode atau coraknya.

\section{Karakteristik Tafsir Modern-Kontemporer}

Kendati Die Richtungen der Islamischen Koranauslegung atau Madhāhib alTafsīr al-Islāmī, karya Ignaz Golzdier (versi terjemahan Dr. 'Alī H\{asan 'Abd Qādir), mendapatkan kritikan dari para peneliti tafsir, tetapi dapat diakui karya itu mendapatkan perhatian dari sejumlah peneliti muslim yang membuat mereka memfokuskan kepada aliran tafsir dengan berbagai karakteristik yang dimilikinya. Antaranya adalah penelitian atas perkembangan tafsir dan cirinya di era kontemporermodern.

Ada lima perspektif atau aliran yang dibagi Ignaz Goldziher; tafsir bi al-ma'thūr (penafsiran atas Qur'an melalui disiplin ilmu hadis dan pandangan sejumlah), tafsir teologi, tafsir tasawuf, tafsir sektarian atau aliran keagamaan, dan tafsir modern. ${ }^{13}$ Goldzhier adalah seorang pemikir kontemporer yang memahami perkembangan tafsir, tetapi ia tidak menyebutkan tafsir kontemporer. Hal ini bisa jadi disebabkan, pengertian modern telah mencakup perkembangan tafsir kontemporer di dalamnya.

Substansi ciri tafsir perspektif modern dan kontemporer adalah menempatkan Qur'an sebagai kitab petunjuk dan mampu menyingkap semangat (ruh) Qur'an itu sendiri, sehingga ini menjadi inti ide para penafsir di masa modern dan kontemporer, utamanya Muh\}ammad 'Abduh ketika melakukan penafsiran terhadap Qur'an. AlQur'an bagi mereka, sudah menjadi keharusan untuk menjadi kitab petunjuk dan keharusan bagi mereka mengeksplore universalitas al-Qur'an yang senantiasa dicari dan dipedomani bagi masyarakat. Kritik mereka terhadap kecenderungan penafsir sebelum mereka ketika menafsirkan Qur'an melalui analisis atas struktur kalimat atau sekadar menguak aspek-aspek teknis kebahasaan atau juga hanya mendeskripsikan pandangan ulama yang saling berbeda pendapat, dan ini tentunya tidak berdampak pengaruh yang signifikan terhadap kehidupan. Sedangkan, penelitian J. G. Jansen, tentang perkembangan tafsir di Mesir, membagi karakteristik tafsir modern dan kontemporer kepada tiga corak tafsir; corak tafsir ilmu atau ilmu pengetahuan (tafsīr 'ilmī), corak tafsir filologi dan sastra (tafsīr adabì), dan corak tafsir sosial. Corak tafsir sosial atau kemasyarakatan ini kemudian kerap disebut dengan adabī ijtimāî̀.

Jika menelusuri karya 'Ali Ḥasan al-'Arīẹī dan karya 'Abd al-H\{ayy al-Farmawī, ditemukan bahwa corak tafsir 'ilmī dan ijtimā'ì, termasuk corak tafsir yang menggunakan metode taḥlīlī. ${ }^{14}$ (walaupun al-'Arīọī sendiri dalam sub judulnya

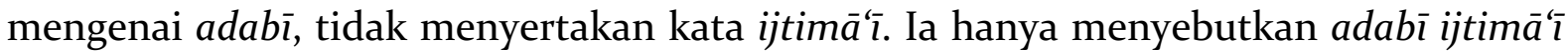
dalam penjelasannya). Ini berarti, bahwa tafsir 'ilmī dan tafsir ijtimā's dapat

\footnotetext{
${ }^{13}$. Lihat Ignaz Goldziher, Madzhab Tafsir: dari Aliran Klasik Hingga Modern (Terj), Yogyakarta: Elsaq Press. 2003, hal. 54.

${ }^{14}$. 'Ali Hasan al 'Aridi, Tārīkh Ilmi al-Tafsīr wa Manāhij al-Mufassirūn (Dār al-I'tisam. H. 74-78 dan 'Abd al-H\{ayy al-Farmawi, Metode Tafsir Maudhu'i dan Cara Penerrapannya (Terj) (Bandung; Pustaka Setia. 2002), 37-38.

170| at-oburhan: Kajian Ilmu dan Pengembangan Budaya Al-Qur'an, Vol. 20, No. 2, Desember 2020: 165-179.
} 
dikategorikan sebagai tafsir modern dan kontemporer dengan penggunaan metode taḥlìì.

Al-Farmawī dan al-'Arīệ̄, tidak menjelaskan corak tafsir ijtimā'ì itu terpisah dengan corak tafsir adabì. Terjadi pemisahan antara adabì dan ijtimāì , itu dapat ditelusuri dalam karya Rachmat Syafei, di mana ia mengutip keterangan dari alSharqawī, tentang perbedaan keduanya. Sayangnya, al-Sharqawī, tidak menawarkan rumusan definitif atas keduanya. Ini yang membuat Rachmat Syafei, berupaya memformulasikan pengertian ijtimā'ì dari sudut bahasa, yaitu tafsir yang berhubungan dengan hal-hal kemasyarakatan. Dengan demikian, adabī ijtimā'î dapat dianggap sebagai corak tafsir baru, karena mengintegrasikan corak tafsir filologi dan sastra (adabì) dengan corak tafsir sosial (ijtmāi $\bar{\imath})$.

Terkait uraian tentang corak tafsir adabi ijtimā'ì , dapat ditelusuri ke dalam karya al-Farmawī. Tafsir adabī ijtimāì berupaya menyingkapkan keindahan bahasa alQur'an dan mukjizat-mukjizatnya; menjelaskan makna dan maksud-maksudnya; memperlihatkan aturan-aturan al-Qur'an tentang kemasyarakatan; dan mengatasi persoalan-persoalan yang dihadap umat islam secara khusus dan permasalahan umat lainnya secara umum. ${ }^{15}$ Semua itu diuraikan dengan memperhatikan petunjuk alQur'an yang membawa kebahagiaan dunia dan akhirat. Corak tafsir ini tampaknya menyatukan antara al-Qur'an dan berbagai teori pengetahuan.

Dari penjelasan al-Farmawī tersebut, Rachmat Syafei, merinci ciri-ciri corak tafsir adabì ijtimāìi.

1. Memperhatikan ketelitian redaksi ayat-ayat al-Qur'an

2. Menguraikan makna dan kandungan ayat-ayat dengan susunan kalimat yang indah

3. Aksentuasi yang menonjol pada tujuan utama turunnya al-Qur'an

4. Penafsiran ayat dikaitkan dengan hukum-hukum alam (sunnah Allāh) yang berlaku dalam masyarakat. ${ }^{16}$

Kemudian, Usman juga menjelaskan empat prinsip tafsir adabī ijtimā'̂̀. ${ }^{17}$. Pertama, setiap surat dalam al-Qur'an dianggap sebagai suatu kesatuan ayat-ayat yang serasi. Maksudnya, setiap ayat pasti mempunyai relevansi dengan ayat lain. Al-Qur'an merupakan mukjizat terbesar. Sebab itu, setiap susunan ayat atau suratnya juga mukjizat. Dengan demikian, munāsabah menjadi niscaya dalam memahami al-Qur'an. Kedua, ayat-ayat al-Qur'an bersifat umum. Tafsir adabī ijtimā'ì sebagai sebuah corak tafsir, berupaya menelusuri sejumlah nilai universal yang terkandung dalam al-Qur'an, sehingga tentu saja tidak bisa diterima begitu saja, manakala suatu ayat ditafsirkan, kemudian kandungan isinya hanya berlaku untuk masyarakat atau periode tertentu saja. Keempat, al-Qur'an sebagai sumber akidah dan hukum. Corak tafsir adabī ijtimā'i berlawanan dengan taklid yang dijadikan sebagai epistemologi ketika menafsirkan alQur'an. Konsep tentang akidah dan hukum harus ditelusuri langsung melalui alQur'an. Al-Qur'an harus dibaca dan digali nilai-nilai di dalamnya. Dengan begitu, alQur'an sungguh menjadi sumber penafsiran. Ini yang menjadikan para penafsir yang menganut corak adabì ijtimā's ì ini menyingkirkan otoritas dan validitas hadis yang

${ }^{15}$ Abd. Aziz Saihu, "Implementasi Metode Pendidikan Pluralisme Dalam Mata Pelajaran Pendidikan Agama Islam Saihu," Belajea: Jurnal Pendidikan Islam 5, no. 1 (2020): 131-50, https://doi.org/10.29240/belajea.v5.

${ }^{16}$. Rachmat Syafei, Pengantar Ilmu Tafsir (Bandung: Pustaka Setia, 2006), 255.

${ }^{17}$ Usman. Ilmu Tafsir (Yogyakarta: Teras, 2009), 300-304.

at-Burhan. Kajian Ilmu dan Pengembangan Budaya Al-Qur'an, Vol. 20, No. 2, Desember 2020: 165-179 | 171 
dinisbatkan kepada sahabat. Kelima, penggunaan daya akal secara luas ketika memahami ayat al-Qur'an. Akal didayagunakan secara benar guna memahami ayat alQur'an. Sebab itu, seorang ahli tafsir yang menghadapi teks al-Qur'an, ia harus menggunakan akal secara maksimal. Sifat rasional melekat pada corak tafsir adabi ijtimā̄ò ini.

Berdasarkan uraian periodisasi, pengertian, dan prinsip adabī ijtimā $\bar{\imath}$, dapat disimpulkan bahwa corak tafsir adabī ijtimā'ì adalah karakteristik utama tafsir modern-kontemporer dengan menggunakan metode tah\}lìlì. Corak ini sesuai dengan realitas dinamika kehidupan dalam berbagai aspek di dalamnya. Intinya, tafsir corak tersebut dapat menjadi solusi atas problematika yang berkembang di era modern dan kontemporer). Ciri corak tafsir adabì ijtimā'ì tersebut dapat diamati melalui para tokoh penggagasnya.

\section{Metode Tafsir}

Kendati dipahami bahwa ahli tafsir memiliki metode berbeda dalam aspek rinciannya dengan ahli tafsir lain. Tetapi, secara general, dapat diketahui bahwa sejak periode III penulisan karya-karya tafsir sampai tahun 1960, para ahli tafsir menafsirkan ayat demi ayat al-Qur'an sesuai sistematikanya dalam mushaf. Penafsiran yang berasaskan urutan mushaf bisa menjadikan petunjuk al-Qur'an terfragmentasi, dan tidak menawarkan kepada para pembacanya secara utuh. Satu persoalan dalam alQur'an kerap dijelaskan secara terpisah dan dalam sejumlah surat. Seperti, tentang riba, dalam Surat al-Baqarah/2, Surat Āli 'Imrān/3, dan Surat al-Rūm/3o. Diperlukan penjelasan terkait ayat-ayat tersebut dalam surat yang berbeda-beda guna mengetahui pandangan al-Qur'an itu sendiri.

Ulama menyadari, terutama al-Shāțibī (w. 1388 M), bahwa setiap surat, kendati persoalan yang dihadapkan itu beragam, tetapi ada satu sentral yang mengikat dan menemukan titik penghubung atas persoalan yang berbeda-beda itu. Pada bulan Januari 196o, Syaykh Mah\}mūd Shaltūt menyusun kitab tafsirnya, Tafsīr al-Qur'ān alKarìm, dalam bentuk penerapan ide yang dikemukakan oleh al-Shātịīi tersebut. Syaltut tidak lagi menafsirkan per ayat, namun membahas per-surat, atau fragmenfragmen khusus dalam satu surat, kemudian merangkainya dengan tema sentral dalam satu surat itu.

Metode ini disebut metode maw belum menjadikan pembahasan tentang petunjuk al-Qur'an terjelaskan secara utuh. Berdasarkan penjelasan atas, satu persoalan bisa didapatkan dalam berbagai surat. Karena itu, muncul timbul ide untuk menyatukan semua ayat yang berkaitan dengan satu masalah tertentu, untuk kemudian dikaitkan satu dengan lainnya, kemudian ditafsirkan secara menyeluruh. Akhir tahun 6o-an, Ah\}mad Sayyid al-Kūmī, mengembangkan ide ini di Mesir. Pada dasarnya, pengembangan ide ini adalah kontinuitas dari metode maw ̣̂ūinnya Mah\}mūd Shaltūt. Oleh karena itu, ada dua pengertian terkait metode maw dūî: Pertama, penafsiran terkait tentang satu surat dalam Qur'an. Tujuan-tujuannya secara umum dan tema sentralnya dijelaskan. Mengorelasikan keragaman persoalan dalam surat tersebut dengan tema tadi. Dengan begitu, suatu surat disertai kompleksitas persoalannya menjadi sebuah kesatuan utuh.

Kedua, penafsiran yang mulanya menghimpun ayat-ayat dalam al-Qur'an yang pembahasannya mengenai satu masalah tertentu dan diurutkan sesuai urutan 
turunnya. Setelah itu, barulah menjelaskan pengertian seluruh ayat-ayat tersebut, untuk mendapatkan petunjuk dari al-Qur'an terkait masalah yang dibahas itu.

\section{Metode Tafsir Modern-Kontemporer}

Ketika menafsirkan Qur'an, ahli tafsir akan merujuk kepada tradisi ulama terdahulu. Kendati ada juga yang merujuk kepada temuan ulama kontemporer. Tafsirtafsir yang merujuk kepada ulama terdahulu, yaitu: 1) Tafsir berdasarkan riwayat, yang dikenal dengan tafsir bi al ma'thūr, 2). Tafsir berdasarkan dirāyah, atau yang terkenal dengan sebutan tafsir bi al-ra'y atau bi al-ijtihādī; 3). Tafsir berdasarkan isyarat, yang dikenal dengan sebutan al-tafsīr al-ishārī. ${ }^{18}$

Pada perkembangannya, yaitu merujuk pada temuan ulama kontemporer, dan ini dianut sejumlah ahli tentang al-Qur'an, seperti sebut saja, al-Farmawī, yang dikembangkan di Indonesia oleh Quraish Shihab, diarahkan kepada pemilahan metode tafsir al-Qur'an kepada empat metode ${ }^{19}$ : Pertama, Ijmālī (Global). Kedua, Taḥlīlì (Analis). Ketiga, Muqārin (Perbandingan). Keempat, Mawọū'ì (Tematik). Metode tafsir berdasarkan riwāyah, dirāyah, dan Ishārī, dimasukkan ke dalam kategori metode klasik. Sementara itu, empat metode; Ijmālì, Taḥlīlì, Muqārin, dan Mawḍūì, yang ditambah satu metode; metode kontekstual (menafsirkan al-Qur'an berdasarkan histori, sosiologi, budaya, adat istiadat, dan pranata-pranata yang berlaku dalam masyarakat Arab, baik sebelum maupun sesudah penurunan al-Qur'an, termasuk ke dalam kategori tafsir kontemporer.

Pengklasifikasian metode tafsir tersebut, tidak bermaksud mendekonstuksi sesuatu yang favorit dan yang tidak favorit, namun lebih kepada memudahkan penelusuran historis atas metode tersebut, dan melengkapi satu sama lainnya.

\section{Metode Tafsir Kontekstual}

Pengertian kontekstual, sekurangnya memuat tiga pengertian:

a. Upaya pemaknaan untuk mengantisipasi problematika yang mendesak untuk direspons, sehingga pengertian sama dengan pengertian situasional.

b. Pemaknaan yang melihat hubungan antara masa lampau dan masa mendatang. Ini maksudnya segala sesuatu dilihat dari sisi makna historis, makna fungsional saat berlangsung, dan memprediksi makna yang bisa jadi memiliki relevansi di masa mendatang.

c. Memosisikan antara yang sentral dan yang periferi. Yang dimaksud sentral adalah teks Qur'an. Sedangkan yang dimaksud periferi adalah terapannya. Di samping itu, memosisikan Qur'an sebagai sentral moral.

Secara substansi, metode kontekstual memiliki hubungan erat dengan Hermeneutika, suatu metode penafsiran teks yang bertolak dari studi bahasa, sejarah, sosiologis, dan filosofis. ${ }^{20}$ Jika metode ini dipertemukan dengan studi teks al-Qur'an, maka persoalan selanjutnya adalah bagaimana ketika teks tersebut hadir di tengah

\footnotetext{
${ }^{18}$ Muḥammad 'Abd al-'Aẓim al-Zarqānī, Manāhil al-'Irfan fì 'Ulūm al-Qur'ān (Kairo: Darussalam, 2010), 387

${ }^{19}$ Ahmad Syukri, Metodologi Tafsir al Qur'an Kontemporer dalam Pandangan Fazlur Rahman (Jambi: Sulton Thaha Press, 2007), 58.

${ }^{20}$ Abd. Aziz, "Refresentasi Semiotika Al-Quran (Analisis Simbol Warna Putih)." Mumtaz: Jurnal Studi Al-Quran dan Keislaman 5.01 (2021): 58-68.

at-\$urhan: Kajian Ilmu dan Pengembangan Budaya Al-Qur'an, Vol. 20, No. 2, Desember 2020: 165-179| 173
} 
masyarakat, kemudian dipahami, diterjemahkan, ditafsirkan, dan didialektikakan dalam menghadapi fakta sosial yang terjadi.

Pada hakikatnya, hermeneutik berhubungan kuat dengan bahasa, yang diekspresikan melalui pikiran, wacana, dan tulisan. Karena itu, hermeneutik merupakan cara baru dalam berinteraksi dengan bahasa. Relasi hermeneutik dengan bahasa menjadikan ranah penafsiran memiliki spektrum yang luas, terutama terkait dengan ilmu humaniora, sejarah, hukum, agama (studi tafsir termasuk di dalamnya), filsafat, seni, sastra, dan linguistik. Yang kerap memanfaatkan hermeneutik adalah ilmu tafsir, lantaran semua karya yang mendapatkan inspirasi Ilahi, seperti al-Qur'an membutuhkan interpretasi atau hermeneutik, sehingga menjadi dipahami. Sementara itu, pengembangan metode hermeneutik oleh para ahli tafsir kontemporer sangat beragam. Tentunya, munculnya keberagaman ini tidak hanya diakibatkan oleh kian terbukanya wawasan umat dalam menghadapi gagasan luar, tetapi juga mencuatnya dinamika dan kesadaran akan kekurangan atas metode yang ada.

Ide tentang metode kontekstual dalam penafsiran Qur'an, digagas oleh Amīn al-Khullī (1895-1966) dan Fazlur Rahman. Kendati tidak ada karya tafsir yang dihasilkan keduanya. Pendekatan metodologi yang diinisiasi Amīn al-Khullī, yaitu teori sastra kontemporer, yakni menyatukan kritik intrinsik dan ekstrinsik dalam menganalisis ayat al-Qur'an, dan studi ini telah mengarhkan kepada hermeneutik teks, sehingga yang mulanya untikable menjadi thinkable. Menurutnya, penggabungan dua perangkat analisis; dirāsah ma'a hawl al-Qur'ān (latar historis, kritik historis, dan kultural ketika diturunkan wahyu) dan dirāsah fi al-qur'ān nafsihi, mutlak dilakukan dalam mengkaji al-Qur'an. Analisis ini memfokuskan kepada struktur tata kata dan kalimat al-Qur'an, diksi, hubungan sintagnasi dan paradigmatis kata, dan aspek lainnya yang memiliki kaitan dengan disiplin linguistik kebahasaan.

Bint al-Shāt\}̄ㅣ, telah berhasil mengimplementasikan pendekatan Amīn al Khullī. Ini dibuktikan dalam karyanya, tafsir al-Bayān li al-Qur'ān al-Karìm, dan Maqāl fi alInsān; Dirāsah Qur'ānīyah. Kendati dalam kata nās (الناس) dan insān (الانسان), menurut Bint Shāṭī, mempunyai makna dasar yang menjelaskan terkait 'manusia,' namun sebenarnya memiliki makna relasi yang berbeda. Menurutnya, kata al-bashar (البشر), berarti manusia secara pengertian biologis, dan ini serupa dengan makhluk lain yang aktivitasnya juga merupakan aktivitas biologis. Sedangkan kata al-insān dan al-nās, berarti manusia sebagai makhluk budaya dan pembuat peradaban. ${ }^{21}$ Pendekatan yang tidak jauh berbeda juga dilakukan oleh Fazlur Rahman. Misalnya ketika ia ingin memahami literal dari kata Riba, menurut al-Qur'an dengan mengemukakan ayat terkait, riba dapat berarti;

1) To grow (berkembang)

Surat al-Hajj/22: 5:

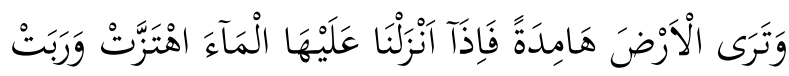

Kamu lihat bumi ini kering, kemudian apabila kami turunkan air di atasnya, hiduplah bumi itu dan berkembang.

${ }^{21}$ Nurkolis Setiawan, “Al-Qur'an dalam Kesejarahan Klasik dan Kontemporer," Jurnal Studi alQur'an (2006); 93.

174 | al-\$urhan: Kajian Ilmu dan Pengembangan Budaya Al-Qur'an, Vol. 20, No. 2, Desember 2020: 165-179. 
2) To increase (meningkat, bertambah)

Surat al-Rūm/30: 39:

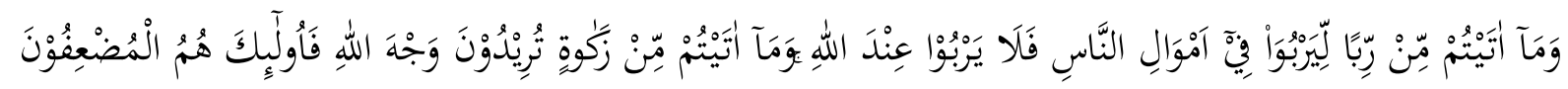

Dan sesuatu riba (tambahan) yang kamu berikan agar harta manusia bertambah, maka tidak bertambah dalam pandangan Allah. Dan apa yang kamu berikan berupa zakat yang kamu maksudkan untuk memperoleh keridaan Allah, maka itulah orang-orang yang melipatgandakan (pahalanya).

3) To rise (naik, misalnya, ke atas bukit)

Surat al Mu'minūn/23: 50:

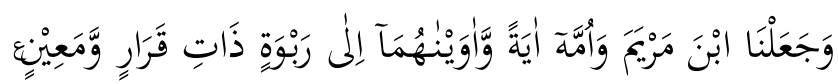

Dan telah Kami jadikan (Isa) putra Maryam bersama ibunya sebagai suatu bukti yang nyata bagi (kebesaran Kami), dan Kami melindungi mereka di sebuah dataran tinggi, (tempat yang tenang, rindang dan banyak buah-buahan) dengan mata air yang mengalir.

Langkah ini disajikan Fazlur Rahman sebagai bagian dari metode tafsir yang disebutnya sebagai gerakan ganda. Pada awalnya, gerakan metode ini dengan cara penelusuran terhadap makna teks yang sejajar dengan konteks ketika Qur'an diturunkan, karenanya harus mempelajari pesan Qur'an secara kronologis. Kemudian perbedaan antara ketetapan hukum dengan tujuan Qur'an, dan mengeksplore prinsipprinsip umum Qur'an dengan cara memahami konteks sosiologis masyarakat Makkah di abad ke-7 M. Kemudian pada gerakan berikutnya, menganalisis situasi sosiologis masyarakat kontemporer untuk kemudian mencari prinsip-prinsip umum yang mana di Qur'an yang nantinya sangat memungkinkan untuk dapat diimplementasikan.

Penjelasan di atas menyimpulkan bahwa diskursus para ahli tafsir modern dibubuhi warna-warni upaya membumikan al-Qur'an dalam kehidupan. Yang hendak dibuktikan adalah bahwa al-Qur'an memang bersifat universal dan mampu mengatasi problematika dan dinamika tantangan zaman. Yang dilakukan para ahli tafsir modern sesungguhnya sebagai bentk ijtihad yang mungkin hanya cocok dengan situasi sosiologis kultural tersendiri. ${ }^{22}$ Sebab itu, keberadaan mereka di tengah khazanah penafsiran modern, tidak menutup diri akan kemunculan para ahli tafsir modern lainnya.

\section{Corak Tafsir Modern Kontemporer}

Penelitian Jansen tentang corak pemikiran para ahli tafsir modern mengarah kepada tiga peta pemikiran, yaitu pemikiran tafsir Ilmi, tafsir Filologi, dan tafsir Adabi Ijtimāî̀. ${ }^{23}$

${ }^{22}$ Made Saihu Et al., "Religion As a Cultural System: A Multiculturalism Education Model in Bali Based on Local Tradition,” Psychology and Education Journal 58, no. 1 (2021): 4198-4206, https://doi.org/10.17762/pae.v58i1.1483.

${ }^{23}$ J. J. G. Jansen. Diskursus Tafsir Islam Modern (Terj.) (Yogyakarta: Tiara Wacana Yogya: 1997), xii-xvi.

al-@urhan: Kajian Ilmu dan Pengembangan Budaya Al-Qur'an, Vol. 20, No. 2, Desember 2020: 165-179 | 175 


\section{Corak Tafsir 'llmī}

Muslim meyakini al-Qur'an mampu mengantisipasi pengetahuan modern. AlGhazālī, memiliki peran strategis dalam memperkenalkan tafsir ini. Kendati pada tataran diskursus modern, keberadaan tafsir ini juga menimbulkan problematika tersendiri. Para pendukung tafsir ini berargumen bahwa keberadaan tafsir Ilmi tersebut merupakan sebuah fenomena wajar. Hal ini memang diisyaratkan oleh alQur'an bahwa segala sesuatu tidak terlewatkan di dalamnya, yaitu dalam surat yang berbunyi: "Tidaklah kami lupakan di dalam al-Kitab, kemudian kepada Tuhanlah mereka dihimpunkan,” (Q.S. al-An'ām [6]: 38). Substansi pemikiran tafsir 'ilmī, dapat ditelusuri kepada sejumlah tokoh, seperti Muhłammad "Abduh, al-Marāghī, Ṭanțāwī Jawharī, Sa'ìd Hawā, dan lainnya. Bahkan, 'Abduh menjelaskan bahwa isyarat penemuan telegraf, telepon, kereta, dan mikrofon, dalam Qur'an sudah ada.

\section{Corak Tafsir Filologi}

Teori-teori penafsiran secara sistematis dikonstruk Ami $>n$ al-Khulli>, menjadi tiga kerangka; 1) Penafsir harus mampu menghubungkan satu ayat dengan ayat lain yang temanya serupa; 2) Menganalisis seluruh makna kata dalam al-Qur'an melalui penggunaan kamus dan menganalisis setiap kata dalam al-Qur'an yang mempunyai akar kata yang serupa; 3) Menganalisis tentang kombinasi yang digunakan al-Qur'an terhadap kata-kata yang ada dalam suatu kalimat. Namun, Ami $>n$ al-Khulli sendiri tidak mengaplikasikan gagasannya tersebut ke dalam bentuk penafsiran terhadap alQur'an. Justru sang istrinya, Bint Shāțī, yang mengaplikasikan gagasan penafsiran terhadap al-Qur'an, sehingga ini yang menjadikan bukti bahwa al-Shāțī adalah penafsir yang memiliki kompetensi di bidang tafsir filologi melalui karya yang diproduksinya, tafsir al-Bayān.

\section{Corak Tafsir Adabī Ijtimā'ì}

Tafsir adabī ijtimā'ì muncul untuk menggugat capaian-capaian tafsir klasik yang dianggap kurang mengakar pada persoalan-persoalan masyarakat. Oleh karena itu, diskursus-diskursus yang mencuat dari madrasah ini adalah kritikan tajam terhadap tafsir klasik. Bagi para mufassir madrasah ini, al-Qur'an baru dapat dikatakan sebagai hudan li al-nās bila telah dirasakan menjadi problem solver bagi persoalan-persoalan kemasyarakatan. Bentuk-bentuk penafsiran yang sifatnya tidak membumi tentu saja tidak mendapat tempat pada madrasah ini. Pokok-pokok pemikiran di atas terlihat jelas pada pendapat Muhammad 'Abduh, Rashīd Rị̣ā, alMarāghī, dan Sayyid Quṭb. 'Abduh menolak tradisi penafsiran klasik yang menggunakan Israiliyat (legenda-legenda Yahudi dan Nasrani) untuk menafsirkan alQur'an, yang dianggapnya mengada-ngada dan mendistorsi tujuan al-Qur'an, yang sebenarnya. Lebih lanjut, ia menjelaskan apa saja yang tidak dijelaskan, memuat isyarat bahwa itu berarti tidak perlu dijelaskan.

\section{Kesimpulan}

Diskursus tafsir maqasidi sebagai bentuk respons metodologi tafsir terhadap situasi terkini yang dihadapi. Respons ini dinilai sebagai salah satu upaya penyingkronan ajaran agama terhadap perkembangan dan penafsiran serta sosial kemasyarakatan. Ini berarti tafsir maqasidi sebagai tafsir modern melakukan 176| at-oburhan: Kajian Ilmu dan Pengembangan Budaya Al-Qur'an, Vol. 20, No. 2, Desember 2020: 165-179. 
konstruksi karya-karya tafsir masa lalu atau klasik menggunakan metode interpretif yang berkembang di masa kontemporer. 


\section{Daftar Pustaka}

Al 'Aridi, 'Ali Hasan. Tarikh Ilmi al-Tafsir wa Manahij al-Mufassirun. Dar al-I'tisam. H. 74-78 dan 'Abd al-Hayy al-Farmawi, Metode Tafsir Maudhu'i dan Cara Penerrapannya (Terj), Baandung; Pustaka Setia. 2002.

Al-Dhahabi, Muhammad Husayn al-Tafsir wa al-Mufassirun. Kairo: Dar al-Hadith, 2012.

Attamimi, Munif Mahadi, and Muhammad Hariyadi. "Al-Qur' an Answering the

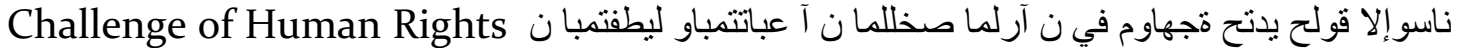

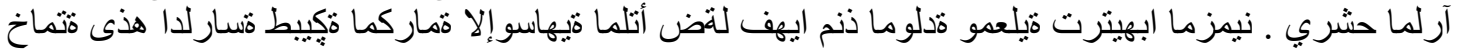

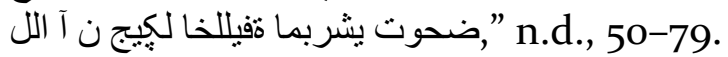

Aziz, Abd. "Refresentasi Semiotika Al-Quran (Analisis Simbol Warna Putih)." Mumtaz: Jurnal Studi Al-Quran dan Keislaman 5.01 (2021): 58-68.

Al-Zarkuni, Muhammad 'Abd al-'Azim. Manahil al-'Irfan fi 'Ulum al-Qur'an. Kairo: Darussalam, 2010, Juz 2.

Baidan, Nasirudin. Perkembangan Tafsir al-Qur'an di Indonesia, Solo: Tiga Serangkai Pustaka Mandiri. 2003.

Departemen Pendidikan Nasional, Kamus Besar Bahasa Indonesia, Jakarta: Pustaka Utama, 2012. Ed. Keempat.

Et al., Made Saihu. "Religion As a Cultural System: A Multiculturalism Education Model in Bali Based on Local Tradition." Psychology and Education Journal 58, no. 1 (2021): 4198-4206. https://doi.org/10.17762/pae.v58i1.1483.

Febriani, Nur Arfiyah, Badru Tamam, M Darwis Hude, Hamdani Anwar, and Muhammad Suaib Tahir. "GLOBAL CITIZENSHIP EDUCATION IN THE PERSPECTIVE OF QUR ' AN AND.” Psychology and Education Journal 57, no. 57 (2020): 5020-29.

Hariyadi, Muhammad. "METODOLOGI TAFSIR AL-QUR'AN KONTEMPORER SALAM PENDEKATAN ILMU KOMUNIKASI MODERN.” Jurnal Statement 11, no. 1 (2021): 30-40.

Hariyadi, Muhammad, and Yusuf Arbi. "Eksposisi Nalar Tafsir Kiai Sholeh Darat; Telaah Transmisi Keilmuan Dan Kontekstualitas Kitab Faidh Ar-Rahman Fi Tarjamah Tafsir Kalam Malik Ad-Dayyan.” Al-Burhan: Jurnal Kajian Ilmu Dan Pengembangan Budaya Al-Qur'an 19, no. 1 (2019): 1-30.

Ignas Goldziher, Madzhab Tafsir: dari Aliran Klasik hingga Modern (Terj), Yogyakarta: el SAQ Press. 2003.

Islamy, Athoillah. "Existence Existence Of Naht Method In The Development Of Contemporary Arabic Language." Taqdir 5.2 (2019): 19-28.

J. J. G. Jansen, Diskursus Tafsir Islam Modern (Terj.), Yogyakarta: Tiara Wacana Yogya: 1997.

Mubin, Fatkhul, and Abd Aziz. "Politik Pendidikan Islam Indonesia: Perlawanan Pesantren Terhadap Hegemoni Pendidikan Barat Era Kolonialisme Belanda." Al Amin: Jurnal Kajian Ilmu dan Budaya Islam 3.1 (2020): 123-136.

Saihu, Abd. Aziz. "Implementasi Metode Pendidikan Pluralisme Dalam Mata Pelajaran Pendidikan Agama Islam Saihu." Belajea: Jurnal Pendidikan Islam 5, no. 1 (2020): 131-50. https://doi.org/10.29240/belajea.v5. 
Salih, 'Abd al-Qadir Muh\}ammad. al-Tafsir wa al-Mufassirun fi al-'Asr Hadith, Beirut: Dar al-Ma'rifah, 2003.

Setiawan, Nurkolis. "Al-Qur'an dalam Kesejarahan Klasik dan Kontemporer," dalam Jurnal Studi al-Qur'an, Ciputat: Pusat Studi al Qur'an, 2006.

Syafei, Rachmat. Pengantar Ilmu Tafsir, Bandung: Pustaka Setia, 2006.

Syukri, Ahmad. Metodologi Tafsir al Qur'an Kontemporer dalam Pandangan Fazlur Rahman. Jambi: Sulton Thaha Press, 2007.

Teungku Muhammad Hasbi ash Shiddiqy. Sejarah dan Pengantar Ilmu al Qur'an dan Tafsir, Semarang: Pustaka Rizki Putra. 2009.

Usman. Ilmu Tafsir, Yogyakarta: Teras, 2009. 